\title{
Macro- and microelements determination in children with rotavirus infection
}

\author{
O. I. Smiyan ${ }^{1}$, K. O. Smiyan-Horbunova ${ }^{1}$, A. M. Loboda ${ }^{1}$, S. V. Popov ${ }^{1}$, T. P. Bynda ${ }^{1}$, \\ I. Yu. Vysotsky ${ }^{1}$, P. I. Sichnenko ${ }^{1}$, V. O. Petrashenko ${ }^{1}$, Yu. A. Man'ko ${ }^{1}$, V. V. Kosarchuk², \\ 0. V. Gordienko ${ }^{1}$
}

${ }^{1}$ Sumy State University, Ukraine, ${ }^{2}$ Military Medical Academy of Ukraine, Kyiv

The purpose of this study was to determine serum zinc, iron, magnesium, copper, potassium, calcium, and sodium levels in acute rotavirus infection and convalescence period in children.

Materials and methods. We examined 86 patients aged from 4 months to 5 years with clinical and laboratory signs of rotavirus infection. The I group - 43 children with RVI in acute period. The II group - 43 children with RVI in convalescence period. The control group included 14 healthy children at the same age. The content of macro- and microelements (zinc, iron, magnesium, copper, potassium, calcium and sodium) in blood serum was determined by atomic absorption spectrophotometry. Feces samples were used for Cito Test Rota (Pharmasco). Cito test was used for rotavirus antigen detection in feces. Statistical analysis was performed by Excel. Student's t-test was used to evaluate differences between study groups.

Results. The acute period of the disease in children with rotavirus infection was characterized by a significant increase of copper in blood serum compared with the control group. At the same time, a significant decrease of iron, magnesium, zinc, potassium, calcium, sodium were determined in patients with rotavirus infection, compared with apparently healthy children. After standard treatment only the indicators of magnesium, potassium and sodium reached the same indices of control group children.

Conclusions. The detected changes in the mineral status of patients with rotavirus infection suggest the need for treatment correction. Correction of micro- and macroelements imbalances in patients with rotavirus infection possibly should be aimed at the metallo-drugs inclusion in complex treatment as well as medicines which improve absorption of the latter in the intestine.

\section{Визначення макро- і мікроелементів у дітей із ротавірусною інфекцією}

О. І. Сміян, К. О. Сміян-Горбунова, А. М. Аобода, С. В. Попов, Т. П. Бинда, І. Ю. Висоцький, П. І. Січненко,

\section{В. О. Петрашенко, Ю. А. Манько, В. В. Косарчук, О. В. Гордієнко}

Мета роботи - визначення рівня сироваткового цинку, заліза, магнію, міді, калію, кальцію та натрію в гострому періоді та в періоді реконвалесценції в дітей із ротавірусної інфрекцією.

Матеріали та методи. Обстежили 86 пацієнтів віком від 4 місяців до 5 років із клінічними та лабораторними ознаками ротавірусної інфекції. I група - 43 дитини з ротавірусною інфекцією в гострому періоді. II група - 43 дитини з ротавірусною інфекцією в період одужання. Контрольна група включала 14 здорових дітей такого самого віку. Вміст мікроелементів - цинку, заліза, магнію, міді, калію, кальцію та натрію - в сироватці крові визначали методом атомної абсорбційної спектрофотометрії. Зразки калу використані для Cito Test Rota (Pharmasco). Cito Test використовували для виявлення ротавирусного антигена у фекаліях. Статистичний аналіз виконали за допомогою ЕхсеІ. Для оцінювання відмінностей між групами використовували t-критерій Стьюдента.

Результати. Гострий період захворювання в дітей із ротавірусною інфекцією характеризувався вірогідним збільшенням вмісту міді в сироватці крові порівняно з контрольною групою. Вірогідне зниження вмісту заліза, магнію, цинку, калію, кальцію, натрію визначили в пацієнтів із ротавірусною інфекцією порівняно з практично здоровими дітьми. Після стандартного лікування тільки показники магнію, калію та натрію досягали відповідних даних у дітей контрольної групи.

Висновки. Виявлені зміни мінерального статусу пацієнтів із ротавірусною інфекцією свідчать про необхідність корекції лікування. Корекція вмісту мікро- та макроелементів у пацієнтів із ротавірусною інфекцією, можливо, повинна бути спрямована на призначення комплексного лікування металовмісними препаратами та засобу для поліпшення його всмоктування в кишечнику.
Key words: rotavirus, children, zinc iron, magnesium, copper, potassium, calcium, sodium.

\section{Zaporozhye} medical journal 2018; 20 (3), 371-374 DOI: $10.14739 / 2310-1210$ 2018.3.130456

E-mail: smiyana@ukr.net

Киючові слова: ротавірус, Аіти, цинк, залізо, магній, міАь, калій, кальцій, натрій.

Запорізький медичний журнал. - 2018. T. 20, № 3(108), C. $371-374$

\section{Определение макро- и микроэлементов у детей с ротавирусной инфекцией}

\section{А. И. Смиян, Е. А. Смиян-Горбунова, А. Н. Аобода, С. В. Попов, Т. П.Бында, И. Ю. Высоцкий, П. И. Сичненко, В. А. Петрашенко, Ю. А. Манько, В. В. Косарчук, Е. В. Гордиенко}

Цель работы - определение уровня сывороточного цинка, железа, магния, меди, калия, кальция и натрия в остром периоде и периоде реконвалесценции у детей с ротавирусной инфекцией.

Материалы и методы. Обследовали 86 пациентов в возрасте от 4 месяцев до 5 лет с клиническими и лабораторными признаками ротавирусной инфекции. I группа - 43 ребенка с ротавирусной инфекцией в остром периоде. II группа - 43 ребенка с ротавирусной инфекцией в период выздоровления. Контрольная группа включала 14 здоровых детей в том же возрасте. Содержание микроэлементов - цинка, железа, магния, меди, калия, кальция и натрия - в сыворотке крови определяли методом атомной абсорбционной спектрофотометрии. Образцы кала использованы для Cito Test Rota (Pharmasco).

Киючевые слова: ротавирус, Аети, цинк, железо, магний, меАь, калий, кальций, натрий.

Запорожский медицинский журнал. - 2018. T. 20, № 3(108). C. $371-374$ 
Cito Test использовали для обнаружения ротавирусного антигена в фекалиях. Статистический анализ выполнен с помощью Excel. Для оценки различий между группами использован t-критерий Стьюдента.

Результаты. Острый период заболевания у детей с ротавирусной инфекцией характеризовался значительным увеличением содержания меди в сыворотке крови по сравнению с контрольной группой. Значительное снижение содержания железа, магния, цинка, калия, кальция, натрия определили у пациентов с ротавирусной инфекцией по сравнению с практически здоровыми детьми. После стандартного лечения только показатели магния, калия и натрия достигали соответствующих данных у детей контрольной группы.

Вывод. Обнаруженные изменения минерального статуса пациентов с ротавирусной инфекцией свидетельствуют о необходимости коррекции лечения. Коррекция содержания микро- и макроэлементов у пациентов с ротавирусной инфекцией, возможно, должна быть направлена на назначение комплексного лечения металлосодержащими препаратами и средствами, способствующими улучшению их абсорбции в кишечнике.

Rotavirus is a member of the family Reoviridae. In all regions of the world rotavirus is the leading cause of hospitalization for gastroenteritis [2]. Rotavirus infection (RVI) is worldwide disseminated disease. Global Enteric Multicenter Study has found that rotavirus is the overall leading cause of moderate to severe diarrhea in children between the ages of 6 month and 2 years old $[3,4]$. Every year, rotavirus causes approximately 114 million episodes of gastroenteritis requiring only home care, 24 million of clinical visits, and 2.4 million of children aged less than 5 years hospitalizations [2]. Rotavirus is responsible for $5 \%$ of all deaths among children worldwide [5]. Also, RVI is the cause of 453000 deaths of young children each year, and more than $85 \%$ of these deaths are accounted in low-income countries [6]. Severe rotavirus gastroenteritis occurs at younger age in developing countries and coinfections with other enteric pathogens [3].

Rotavirus can get into the human body mainly with a fecal-oral mechanism of the transmission by means of contaminated hands, environmental surfaces and objects, and occasionally by food and water $[7,8]$. The clinical manifestation of RVI includes a wide range of symptoms from asymptomatic infection to severe diarrhea with dehydration. Children with RVI have clinical symptoms that vary from mild illness with mild diarrhea of short duration to recurrent profuse diarrhea with high fever and vomiting that can lead to dehydration with electrolyte imbalance and even death. RVI usually starts with severe attack of fever and vomiting that lasts one or two days, followed by watery diarrhea which generally continues for three to seven days [1].

The micro- and macroelements are important because of their essential functions despite the small amount required. Bioelements deficiencies in children of most developing countries are related to their deficit in the common food items. Zinc, iron, magnesium, copper, potassium, calcium, sodium are essential micri- and macronuntrients for growth and morbidity development. These elements are regularly needed for protein synthesis, bone mineralization, physical growth, and biological functions such as immunity [9].

Carlson et al. used animal model for study which showed that zinc helps to maintain the integrity of the intestinal mucosa [10]. Yakoob et al. reported that reduction of diarrhea mortality in children was due to zinc supplements [11]. Serum zinc levels of the patients admitted to hospital for acute gastroenteritis without any other disease and without moderate or severe malnutrition were not affected by the disease state. Gastroenteritis did not further decrease serum zinc levels in patients with asymptomatic or subclinical zinc deficiency [12]. Zn concentrations in serum significantly increased in remission as compared with admission to hospital in children with viral infections [13].

\section{Aim}

We conducted a study to determine serum zinc, iron, magnesium, copper, potassium, calcium, and sodium levels in acute rotavirus infection and convalescence period in children.

\section{Materials and methods}

Our investigation comprised 43 patients aged from 4 months to 5 years with clinical and laboratory signs of rotavirus infection. The I group - 43 children with RVI in acute period, which were patients of St. Zinaida city children clinical hospital, Sumy, Ukraine. The II group - 43 children with $\mathrm{RVI}$ in convalescence period. The control group included 14 healthy children at the same age. All children were enrolled in the study after informed consent of their parents or guardians. Ethical approval was obtained from Institutional research ethics committees.

Criteria for inclusion:

- age from 4 months to 5 years;

- rotavirus infection;

- hospitalization in acute phase of the disease;

- informed consent of children's parents or guardians;

- absence of comorbidities in patients;

- children didn't take drugs, which contributed to the change in the amount of trace elements.

Criteria for exclusion:

- age less than 4 months or more than 5 years;

- hospitalization in mild phase of the disease;

- children's parents or guardians didn't give informed consent;

- presence of comorbidities in children.

Feces samples were collected in a sterile container at admission to the hospital. These samples were used for Cito Test Rota (Pharmasco). Cito test was used for rotavirus antigen detection in feces.

In the morning fasting venous blood samples were obtained from children with rotavirus into sterile tubes for trace elements analysis. After two hours keeping and centrifugation at $3500 \mathrm{rpm}$ for 10 minutes, blood serum was separated. The serum samples were put in closed plastic laboratory tubes and stored at $-18^{\circ} \mathrm{C}$ until trace elements were analyzed.

The content of trace elements of zinc, iron, magnesium, copper, potassium, calcium, and sodium in blood serum was determined by atomic absorption spectrophotometry (AAS) on a spectrophotometer C-115MI (JSC "Selmi", Ukraine) $[14,15]$. All results of trace elements analysis in patients were compared with healthy controls. The content 
of trace elements in blood serum in comparison group was determined by AAS.

Statistical analysis was performed by Excel (Microsoft Corporation, Redmond, WA). Student's t-test was used to evaluate differences between study groups. Statistically significant differences were indicated by $p$ values $<0.05$.

\section{Results and discussion}

For determination of trace element provision in children with rotavirus infection, we have determined the content of copper, iron, zinc, magnesium, potassium, calcium, and sodium in the acute phase of the disease (1-3 days) and convalescence period (7-10 days) (Table 1).

The acute period of the disease in children with rotavirus infection was characterized by a significant increase of copper in blood serum to $20.15 \pm 0.34 \mathrm{mcmol} / /$ compared to the same period of the control group $(12.36 \pm 0.33 \mathrm{mcmol} / \mathrm{l}$ $(P<0.001))$. At the same time, a significant reduction of iron was determined in patients of group I, it was $6.45 \pm 0.21$ $\mathrm{mcmol} / \mathrm{l}$ compared with apparently healthy children who had $11.42 \pm 0.48 \mathrm{mcmol} / \mathrm{l}(P<0.001)$. Similar changes were related to the content of zinc which was $6.15 \pm 0.31$ $\mathrm{mcmol} / \mathrm{l}$, lower than that of children in the control group $(13,56 \pm 0,37 \mathrm{mcmol} / \mathrm{l}(P<0.001))$. Patients with RVI were characterized by a significant decrease of magnesium in blood plasma to $0.66 \pm 0.03 \mathrm{mcmol} / \mathrm{l}$, compared to the same index in the control group children $(0.97 \pm 0.05 \mathrm{mcmol} / \mathrm{l}$ $(P<0.001))$.

In acute phase of the disease patients of the group I had potassium and calcium content of $4.07 \pm 0.15 \mathrm{mcmol} / \mathrm{l}$ and $1.67 \pm 0.05 \mathrm{mcmol} / \mathrm{l}$, respectively, which was lower than the level of the same elements in healthy children $(5.12 \pm 0.13 \mathrm{mcmol} / \mathrm{l}$ and $2.76 \pm 0.05 \mathrm{mcmol} / /$, respectively, $(P<0.001))$. In addition, the reduction of sodium in blood plasma to $147.32 \pm 1.62 \mathrm{mcmol} / \mathrm{l}$ was determined in the given group of patients compared to the same index in children of the control group $(152.43 \pm 1.87 \mathrm{mcmol} / \mathrm{l}(P<0.001))$.

After standard treatment there was no complete normalization of micro- and macroelements content of the studied parameters in children of the group I. In the period of convalescence magnesium level increased significantly to $1.02 \pm 0.05 \mathrm{mcmol} / \mathrm{l}(\mathrm{P}<0.001)$ in patients with $\mathrm{RVI}$. In addition, potassium and calcium concentration in blood serum increased in children of the group I, it was $4.78 \pm 0.16$ $\mathrm{mcmol} / \mathrm{l}$ and $2.15 \pm 0.06 \mathrm{mcmol} / \mathrm{l}$, respectively, $(P<0.01)$. At the same time, in children of this group copper index tended to decrease, and iron, zinc and sodium - to increase $(P>0.05)$.

It is known that zinc is the main component that regulates the activity of immune system; it is the factor of nonspecific immune protection that is required for the maturation of specific immune cells and cytokine production. Reducing its number in children with RVI may indirectly constitute the immune system dysfunction and organism resistance impairment. Since copper is a part of oxidative enzymes, and the processes of free radical oxidation increase in acute phase of the disease, the need for these enzymes also increases. All these facts may contribute to copper release from the depot and its active participation in metabolic processes. According to scientific references, iron exchange in the body has a close relationship with
Table 1. Dynamics of micro- and macroelements concentrations in blood serum of children with mono and mixed RVI, $\mathrm{M} \pm \mathrm{m}$

\begin{tabular}{|c|c|c|c|}
\hline \multirow[t]{2}{*}{ ME } & Control group $(n=14)$ & I group $(n=43)$ & II group $(n=43)$ \\
\hline & 1 & 2 & 3 \\
\hline Copper, mcmol/l & $12.36 \pm 0.33$ & $\begin{array}{l}20.15 \pm 0.34 \\
P_{1-2}<0.001\end{array}$ & $\begin{array}{l}19.63 \pm 0.36 \\
P_{1-3}<0.001 \\
P_{2-3}>0.05\end{array}$ \\
\hline Iron, $\mathrm{mcmol} / \mathrm{l}$ & $11.42 \pm 0.48$ & $\begin{array}{l}6.45 \pm 0.21 \\
P_{1-2}<0.001\end{array}$ & $\begin{array}{l}7.13 \pm 0.32 \\
P_{1-3}<0.001 \\
P_{2-3}>0.05\end{array}$ \\
\hline Zinc, mcmol/l & $13.56 \pm 0.37$ & $\begin{array}{l}6.15 \pm 0.31 \\
P_{1-2}<0.001\end{array}$ & $\begin{array}{l}6.56 \pm 0.36 \\
P_{1-3}<0.001 \\
P_{2-3}>0.05\end{array}$ \\
\hline Magnesium, mcmol/l & $0.97 \pm 0.05$ & $\begin{array}{l}0.66 \pm 0.03 \\
P_{1-2}<0.001\end{array}$ & $\begin{array}{l}1.02 \pm 0.05 \\
P_{1-3}>0.05 \\
P_{2-3}<0.001\end{array}$ \\
\hline Potassium, $\mathrm{mcmol} / \mathrm{l}$ & $5.12 \pm 0.13$ & $\begin{array}{l}4.07 \pm 0.15 \\
P_{1-2}<0.001\end{array}$ & $\begin{array}{l}4.78 \pm 0.16 \\
P_{1-3}>0.05 \\
P_{2-3}<0.01\end{array}$ \\
\hline Calcium, mcmol/l & $2.76 \pm 0.05$ & $\begin{array}{l}1.67 \pm 0.05 \\
P_{1-2}<0.001\end{array}$ & $\begin{array}{l}2.15 \pm 0.06 \\
P_{1-3}<0.001 \\
P_{2-3}<0.001\end{array}$ \\
\hline Sodium, mcmol/l & $152.43 \pm 1.87$ & $\begin{array}{l}147.32 \pm 1.62 \\
P_{1-2}<0.05\end{array}$ & $\begin{array}{l}150.21 \pm 1.85 \\
P_{1-3}>0.05 \\
P_{2-3}>0.05\end{array}$ \\
\hline
\end{tabular}

$P_{1-2}$ : difference between indexes of control group children and group I in acute phase; $P_{1-3}$ : difference between indexes of control group children and group I in convalescence phase; $\mathbf{P}_{2.3}$ : difference between indexes of group I children in acute and convalescence phases.

the immunologic reactivity. Therefore, the reduction of iron in blood serum may possibly be due to its significant demand in the body for normalization of immunoreactivity impaired function in patients under investigation.

Thus, this study has shown a significant decrease in iron, magnesium, zinc, potassium, calcium, sodium, and copper increase in blood serum in early phase of the disease in children with rotavirus infection. After standard treatment only the indicators of magnesium, potassium and sodium reached the same indices of the control children group. The detected changes in the mineral status of patients with rotavirus infection suggest the need for treatment correction.

\section{Conclusions}

1. The acute phase of the disease in patients with rotavirus infection is characterized by micro- and macroelements imbalances in blood serum when compared with those of healthy children, which are determined by a significant decrease in iron, magnesium, zinc, potassium, calcium, sodium, and increase in copper.

2. After standard treatment only the indicators of magnesium, potassium and sodium reached the same indices of control children group.

Prospects of further scientific research. A promising study will be the correction of micro- and macroelements imbalances in patients with rotavirus infection. Correction possibly should be aimed at the metallo-drugs inclusion in complex treatment as well as medicines which improve absorption of the latter in the intestine.

Conflicts of Interest: authors have no conflict of interest to declare. Конфмікт інтересів: віАсутній. 
Information about authors:

Smiyan 0. I., MD, PhD, DSc, Professor, Department of Pediatrics,

Sumy State University, Ukraine.

Smiyan-Horbunova K. O., MD, PhD, Assistant, Department

of Pediatrics, Sumy State University, Ukraine.

Loboda A. M., MD, PhD, DSc, Director of Medical Institute, Sumy

State University, Ukraine.

Popov S. V., MD, PhD, DSc, Professor, Department of Pediatrics, Sumy State University, Ukraine.

Bynda T. P., MD, PhD, Assosiate Professor, Department

of Pediatrics, Sumy State University, Ukraine.

Vysotsky I. Yu., MD, PhD, DSc, Professor, Department

of Biophysics, Biochemistry, Pharmacology and Biomolecular

Engineering, Sumy State University, Ukraine.

Sichnenko P. I., MD, PhD, Assosiate Professor, Department

of Pediatrics, Sumy State University, Ukraine.

Petrashenko V. O., MD, PhD, Assosiate Professor, Department

of Pediatrics, Sumy State University, Ukraine.

Man'ko Yu. A., MD, PhD, Assistant, Department of Pediatrics,

Sumy State University, Ukraine.

Kosarchuk V.V., MD, PhD, DSc, Professor, Department of Medical

Support of Armed Forces, Military Medical Academy of Ukraine,

Kyiv, Ukraine.

Gordienko O. V., Assistant, Department of Morphology, Sumy

State University, Ukraine.

\section{Відомості про авторів:}

Сміян 0. І., А-р меА. наук, професор, зав. каф. пеАіатрії,

Сумський Аержавний університет, Україна.

Сміян-Горбунова К. О., канА. меА. наук, асистент каф. педіатрії,

Сумський Аержавний університет, Україна.

^обода А. М. А-р меА. наук, Аиректор медичного інституту,

Сумський Аержавний університет, Україна.

Попов С. В., А-р меА. наук, професор каф. педіатрії, Сумський Аержавний університет, Україна.

Бинда Т. П., канА. меА. наук, доцент каф. педіатрії, Сумський Аержавний університет, Україна.

Висоцький І. Ю., А-р меА. наук, професор каф. біофізики, біохімії, фармакології та біомолекулярної інженерії, Сумський Аержавний університет, Україна.

Січненко П. І., канА. меА. наук, Аоцент каф. педіатрії, Сумський Аержавний університет, Україна.

Петрашенко В. О., канА. меА. наук, Аоцент каф. педіатрії, Сумський Аержавний університет, Україна.

Манько Ю. А., канА. меА. наук, асистент каф. педіатрії, Сумський Аержавний університет, Україна.

Косарчук В. В., А-р меА. наук, професор каф. організації медичного забезпечення військ Збройних Сил, Українська військово-меАична академія, м. Київ.

Гордієнко О. В., асистент каф. морфології, Сумський державний університет, Україна.

\section{Сведения об авторах:}

Смиян А. И., А-р меА. наук, профессор, зав. каф. педиатрии, Сумский государственный университет, Украина.

Смиян-Горбунова Е. А., канА. меА. наук, ассистент каф. педиатрии, Сумский государственный университет, Украина.

ヘобода А. М., А-р меА. наук, Аиректор мединститута, Сумский государственный университет, Украина.

Попов С. В., А-р меА. наук, профессор каф. пеАиатрии, Сумский государственный университет, Украина.

Бында Т. П., канА. меА. наук, Аоцент каф. педиатрии, Сумский государственный университет, Украина.

Высоцкий И. Ю., А-р меА. наук, проф. каф. биофизики, биохимии, фармакологии и биомолекулярной инженерии, Сумский государственный университет, Украина. Сичненко П. И., канА. МеА. наук, Аоцент каф. педиатрии, Сумский государственный университет, Украина. Петрашенко В. А., канА. МеА. наук, Аоцент каф. педиатрии, Сумский государственный университет, Украина.

Манько Ю. А., канА. меА. наук, ассистент каф. педиатрии, Сумский государственный университет, Украина.

Косарчук В. В., А-р меА. наук, профессор каф. организации медицинского обеспечения войск Вооруженных Сик,

Украинская военно-медицинская академия, г. Киев.
Гордиенко А. В., ассистент каф. морфологии, Сумский государственный университет, Украина.

Надійшла до редакції / Received: 28.09.2017

Після Аоопрацювання / Revised: 17.10.2017

Прийнято Ао Аруку / Accepted: 09.11.2017

\section{References}

[1] Krawczyk, A., Lewis, M. G., Venkatesh, B. V., \& Nair, S. N. (2016). Effec of Exclusive Breastfeeding on Rotavirus Infection among Children. Indian J Pediatr., 83(3), 220-225. doi: 10.1007/s12098-015-1854-8.

[2] Dennehy, P. H. (2015). Rotavirus Infection A Disease of the Past? Infectious Disease Clinics of North America, 29(4), 617-635. doi: 10.1016/j. idc.2015.07.002.

[3] Parashar, U. D., Nelson, A., \& Kang, G. (2013). Diagnosis, management, and prevention of rotavirus gastroenteritis in children. BMJ, 347 , f7204. doi: 10.1136/bmj.f7204.

[4] Kotloff, K. L., Nataro, J. P., Blackwelder, W. C. Nasrin, D., Farag, T. H. Panchalingam, S., et al. (2013). Burden and aetiology of diarrhoeal disease in infants and young children in developing countries (the Global Enteric Multicenter Study, GEMS): a prospective, case-control study. Lancet, 382(9888), 209-222. doi: 10.1016/S0140-6736(13)60844-2.

[5] Ribas, M. de L., Tejero, Y., Cordero, Y., de Los Angeles León, M. Rodriguez, M., Perez-Lastre, J., et al. (2015). Detection of rotavirus and other enteropathogens in children hospitalized with acute gastroenteritis in Havana, Cuba. Arch Virol., 160(8), 1923-1930. doi: 10.1007/ s00705-015-2458-3.

[6] Tate, J. E., Burton, A. H., Boschi-Pinto, C., Steele, A. D., Duque, J., \& Parashar, U. D. (2012). 2008 estimate of worldwide rotavirus associated mortality in children younger than 5 years before the introduction of universal rotavirus vaccination programmes: a systematic review and meta-analysis. Lancet Infect Dis., 12(2), 136-141. doi: 10.1016/ S1473-3099(11)70253-5

[7] Yen, C., Tate, J., Patel, M., Cortese, M., Lopman, B., Fleming, J., et al. (2011) Rotavirus vaccine. Update of global impact and future priorities. Human vaccines, 7(12), 1282-1290. doi: 10.4161/hv.7.12.18321

[8] Dennehy, P. H., Cortese, M. M., Bégué, R. E., Jaeger, J. L., Roberts, N. E., Zhang, R., et al. (2006). A case-control study to determine risk factors for hospitalization for rotavirus gastroenteritis in US children. Pediatr Infect Dis J., 25, 1123-1131. doi: 10.1097/01. inf.0000243777.01375.5b.

[9] Lamberti, L. M., Walker, C. L. F., Chan, K. Y., Jian, W. Y., \& Black, R. E. (2013). Oral zinc supplementation for the treatment of acute diarrhea in children: a systematic review and meta-analysis. Nutrients, 5(11) 4715-4740. doi: 10.3390/nu5114715.

[10] Carlson, D., Sehested, J., \& Poulsen, H. D. (2006). Zinc reduces the electrophysiological responses in vitro to basolateral receptor mediated secretagogues in piglet small intestinal epithelium. Comparative Biochemistry and Physiology. Part A: Molecular and Integrative Physiology, 144, 514-519. doi: 10.1016/j.cbpa.2006.04.019.

[11] Yakoob, M. Y., Theodoratou, E., Jabeen, A., Imdad, A., Eisele, T. P., Ferguson, J., et al. (2011). Preventive zinc supplementation in developing countries: impact on mortality and morbidity due to diarrhea, pneumonia and malaria. BMC Public Health, 11(3), 3-23. doi: 10.1186/14712458-11-S3-S23.

[12] Akgün, Ö., Songül, S. Y., Kadriye, Y., \& Turgay, C. (2007). Serum zinc levels in children with acute gastroenteritis. Pediatrics International, 49(3), 314-317. doi: 10.1111/j.1442-200X.2007.02371.x.

[13] Karakonstantakis, T., Papassotiriou, I., Sergounioti, A., Moraitis, P., Theodoridou, K., Afordakou, D., et al. (2012). Evaluation of zinc and selenium alterations in children with acute infections: Correlation with markers of inflammation. Interventional Medicine and Applied Science, 4(1), 15-20. doi: 10.1556/IMAS.4.2012.1.4.

[14] Sunderman, F. W. Jr., Marzouk, A., Crisostomo, M. C., \& Weatherby, D. R. (1985). Electrothermal atomic absorption spectrophotometry of nickel in tissue homogenates. Annals of Clinical and Laboratory Science, 15(4), 299-307.

[15] Brzozowska, B., \& Zawadzka, T. (1981). Atomic absorption spectrophotometry method for determination of Lead, Cadmium, Zinc and Copper in various vegetable products. Roczniki Panstwowego Zakladu Higieny, 32(1), 9-15. 